\title{
User Interface Menu Design Performance and User Preferences: A Review and Ways Forward
}

\author{
Dr Pietro Murano \\ Department of Computer Science, The Universal Design of \\ ICT Research Group \\ Oslo and Akershus University College of Applied Sciences, \\ Oslo, Norway
}

\begin{abstract}
This review paper is about menus on web pages and applications and their positioning on the user screen. The paper aims to provide the reader with a succinct summary of the major research in this area along with an easy to read tabulation of the most important studies. Furthermore, the paper concludes with some suggestions for future research regarding how menus and their positioning on the screen could be improved. The two principal suggestions concern trying to use more qualitative methods for investigating the issues and to develop in the future more universally designed menus.
\end{abstract}

Keywords-Menus; navigation of interfaces; universal design; research methods

\section{INTRODUCTION}

The research and practical problem of how to design navigation methods or menus for web sites and applications has been around for some time. Many have opinions regarding which type of menu is best for users and this is reflected in the web sites we can see on the internet. However, most web sites seem to employ either a left or right vertically positioned menu or a horizontal top positioned menu, with some web sites sometimes opting for a combination of two or more styles of menu (e.g. see [1]). Many web sites also use the bottom horizontal part of a screen to position a form of menu (e.g. see [2]). Some are also more unique, by placing a horizontal menu in the middle of the screen (e.g. see [3]).

Despite the opinions and numerous studies around this subject, there are still unanswered questions regarding which menu position or design might be optimal in terms of performance and user preference.

Therefore, this paper is a review paper of the most relevant research conducted around evaluating menu types and their positioning on the screen. It is hoped that other researchers can benefit from this work, because it helps to bring together in one place a number of sources from diverse authors and publications that can be difficult to find in general searches. In addition, this review will focus on looking into the main issues of this field and to find any unexplored aspects in the field. The authors will also recommend some potential ways forward. This review paper should be of benefit to researchers working in this area, students of computer science and any professional designer or developer involved in menu design and implementation.

\author{
Margrete Sander \\ Department of Computer Science, The Universal Design of \\ ICT Research Group \\ Oslo and Akershus University College of Applied Sciences, \\ Oslo, Norway
}

Furthermore, the authors acknowledge that there are in existence certain types of menus that are less conventional and less used in every day applications and web sites, e.g. radial and flower menus. Please see Rubio and Janecek [4], Samp and Decker [5], Bailly, Lecolinet and Nigay [6] and Murano and Khan [7] for some examples. Discussions of these will be deliberately not included in this review paper, as the authors wish to focus on menus which are more commonly used and hopefully can contribute some ways forward to the existing patterns of menu use. Clearly, if radial and flower menus should become more main stream, then a future review should deal with this category of menu too.

In section II, this paper will proceed by presenting the authors' salient selection of relevant papers. This will be followed by a summary table of the most important papers covered so as to allow a more 'at a glance' option for quick reference. In section III, some ways forward are proposed for further investigation into this subject. Lastly, in section IV, the overall conclusions are presented.

\section{REVIEW OF THE MOST RELEVANT WORKS}

There have been studies investigating all manner of aspects to do with navigation or presentation of information.

Pittsley and Memmott [8] investigated issues of users not noticing certain navigation cues on web pages designed for information retrieval in a US university library web site for research purposes.

They tested some changes to the user interface. The redesign used in the evaluation involved a tabbed horizontal menu and left vertical context menu with larger font (both with the same labels) and a larger tabbed horizontal menu only. They also had a 'Comparison group' which was not fully described in the paper. They collected monthly usage on each information guide, page and secondary pages as a guide to show if the redesigns had been successful. Their basic findings were that both prototype 'menus' showed an increase in secondary page hits compared to the 'comparison group'.

In another study by Melguizo, Vidya and van Oostendorp [9], menu types, the complexity of a navigation path and the users' spatial skills in relation to finding web information were investigated. They also looked at 'web disorientation'.

There were two types of menu studied, left vertical expandable and left vertical sequential. They measured task 
accuracy, task response time and lostness. The primary results of their work were that there was no significant difference for menu type and task accuracy, task response time and lostness. However, they did see some differences in relation to users with high or low spatial ability. Their results suggest that users with high spatial abilities perform well in all their conditions. Users with low spatial abilities seem to generally perform better with expandable menus.

A different study by Patsula, Detenber and Theng [10] involved web menus, with the emphasis on investigating the 'structure processing mechanism' in human working memory.

In the first study they compared a structured rule-based menu, a structured semantic-based menu, an unstructured mismapped menu and an unstructured random design. They recorded retention, time, errors and subjective opinions. The actual context of the menus involved abstract content consisting of arbitrary words and characters. Based on a statistical analysis and interviews their results showed retention, time and errors were better with the structured menus. Further, almost half of all participants felt the unstructured menus needed more mental effort.

In the second study they compared a more realistic context using structured menus, based on the PhotoImpression 3.0 application and unstructured menus, based on the Norton Anti Virus 4.0 application. They recorded retention, time, errors and subjective opinions. Based on a statistical analysis, a questionnaire and interviews their results showed retention, time and errors were better with the structured menus. Also, participants seemed to engage in behaviour involving structure processing.

Another study to be considered is by Leuthold, Schmutz, Bargas-Avila, Tuch, and Opwis [11]. In this investigation they tested three types of vertical menu placed on the left side of a page. These were a simple menu, extended menu and a dynamic menu. Their context was an ecommerce web site. The principal data was recorded in terms of number of eye fixations, the time to do the first click, the correctness of the first click, the navigation strategy and subjective opinions.

The central results they achieved were that first clicks were more successful for complex and simple tasks with the extended menu. For simple tasks, participants used fewer eye fixations with the extended menu. For complex tasks participants used fewer eye fixations with the extended menu. For simple tasks participants were faster with the simple menu. For complex tasks participants were faster with the extended menu. Lastly, the extended menu was perceived by participants to be easier and more helpful than the other two menus.

One of the authors of this paper has been investigating menu design for a few years and in Murano and Oenga [12] the details of an experiment were described. A left vertical menu and a fisheye menu placed horizontally at the top of a page were studied in the context of a simulated supermarket web site and compared with a real supermarket web site which had a horizontal menu at the top of the screen. No major differences in the two designs were observed. One of the reasons for not observing any differences in the data collected could have been due to the tasks being too easy for participants. However it could also have been some confounding variable.

This resulted in another experiment conducted by Murano and Lomas [13] where the tasks were designed to be more demanding than in the study by Murano and Oenga [12]. An experiment with four conditions was executed, which had the context of a simulated web shop. The four conditions examined four different menu positions (left, right, top and bottom of the screen). Overall, the top and left placed menus elicited fewer errors and less mouse clicks in users. Also users' preferences generally were in the same direction with the results for errors and mouse clicks.

In another study by Bernard, Hamblin and Chaparro [14] different menu layouts were compared. The first layout they used, was an 'index menu'. This had menu options as links in the centre of the screen. The second was a 'horizontal menu', which was at the top of the screen. The third was a 'vertical menu', which appeared at the left side of the screen. They observed that the 'index menu' performed best and was also preferred by the users. They also observed that the 'horizontal menu' was the worst in terms of performance and preference.

In a study by Burrell and Sodan [15], the position of menus on the screen was studied. They studied six different menu positions. In relation to a screen, these were: top tabbed, top, left, top and bottom, top and left and top and right of the screen. Some web site context was used in their study and their data showed them that the tabbed menu was liked more by the users.

Moreover, McCarthy, Sasse and Riegelsberger [16] looked at menu positioning in the context of a web site. They had a complex and simple version of the web site. They then had three menu positions. These were left, top and right of the screen. The time taken for a task was significantly longer with the complex web site. However the menu positions described above were not statistically significant in difference when averaged across the tasks and the simple and complex web sites. The left sided menu performed better concerning interaction with the first web page. No differences for the second page were recorded.

Also Fang and Holsapple [17] did an interesting study looking at navigation structures for web sites. They specifically looked at three types of hierarchy. These were: 'subjectoriented, usage-oriented' and a combination of the first two. Further, they had some simple and complex tasks. Fang and Holsapple observed that the 'usage-oriented' and the combined form of hierarchy indicated increased usability when compared with the 'subject-oriented' hierarchy.

Furthermore, Yu and Roh [18] studied different menus. They studied 'a simple selection menu, a global and local navigation menu and a pull-down menu'. These were tested via an ecommerce web site. Participants were then used to perform some tasks in the context of information finding about products. The principal results indicated that the pull-down menu was faster for searching. However, the performance in browsing task speed was stronger in the global and local navigation menus. The users preferences were approximately the same in the three experimental conditions. 
In a more industrial and realistic context, Kalbach and Bosenick [19] did an evaluation for the Audi Cars web site. In this context, they evaluated linear menus on the left and right sides of the screen, using the Audi web site. They observed no significant differences for task times and the two menu styles they tested.

In a study by Faulkner and Hayton [20], they evaluated left and right placed menus. This was in the context of an ecommerce web site, selling Christmas products. For tasks involving purchasing something, there were no significant differences in the times taken.

The review above has shown that there are many different types of results, which have been achieved with many different forms of menu or navigation. In order to help visualise and see what has been done more at a glance, the table below tabulates the above endeavours. Only what the authors have considered to be pertinent to this paper have been included in the table and it is suggested that if a particular work seems interesting, then the full paper should be accessed. Furthermore, in the table, use of the word 'statistical' is made. The authors here are using the word loosely, because different authors of the research cited have used different 'statistical' techniques. In some cases, they tend to be more about presenting high level 'statistics', while on certain other occasions more in-depth significance testing has been done. The same applies to the word 'experimental' used in the table. This is used loosely, because across all the studies shown in the table, the fundamental characteristics of what was done point to an 'experimental' type method. However, the degree of rigour and robustness of how the studies were conducted varies within this set of papers. Some experiments were very rigorous and some less so. 


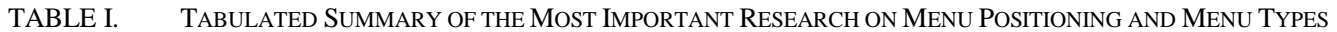

\begin{tabular}{|c|c|c|c|c|c|c|}
\hline \multirow{2}{*}{ Authors } & \multicolumn{3}{|c|}{ What Was Evaluated } & \multirow{2}{*}{ Method } & \multirow{2}{*}{$\begin{array}{c}\text { Type of } \\
\text { Analysis }\end{array}$} & \multirow{2}{*}{ Significant Results } \\
\hline & $\begin{array}{c}\text { Menu } \\
\text { Position/Type }\end{array}$ & $\begin{array}{l}\text { Dependent } \\
\text { Measures }\end{array}$ & Context & & & \\
\hline $\begin{array}{c}\text { Faulkner, Hayton, } \\
2011,[20]\end{array}$ & Left, Right. & Time. & $\begin{array}{c}\text { Ecommerce web } \\
\text { site. }\end{array}$ & $\begin{array}{l}\text { Experime } \\
\text { ntal }\end{array}$ & Statistical & None. \\
\hline $\begin{array}{c}\text { Kalbach, } \\
\text { Bosenick, 2003, } \\
{[19]}\end{array}$ & Left, Right. & $\begin{array}{l}\text { Time, Subjective } \\
\text { Opinion. }\end{array}$ & $\begin{array}{l}\text { Ecommerce } \\
\text { web. site }\end{array}$ & $\begin{array}{l}\text { Experime } \\
\text { ntal }\end{array}$ & $\begin{array}{l}\text { Statistical } \\
\text { Interview } \\
\text { s. }\end{array}$ & None. \\
\hline $\begin{array}{c}\text { Yu, Roh, 2002, } \\
{[18]}\end{array}$ & $\begin{array}{l}\text { Top, Combination } \\
\text { Top/Left. }\end{array}$ & $\begin{array}{l}\text { Time (searching } \\
\text { and browsing), } \\
\text { Subjective Opinion. }\end{array}$ & $\begin{array}{c}\text { Ecommerce web } \\
\text { site. }\end{array}$ & $\begin{array}{l}\text { Experime } \\
\text { ntal }\end{array}$ & Statistical & $\begin{array}{l}\text { Pull down top menu faster for searching. For } \\
\text { browsing simple selection menu slowest. Similar } \\
\text { to left vertical, but each sub-menu overlays the } \\
\text { previous menu and not full left justified. Not } \\
\text { significant for subjective opinion. }\end{array}$ \\
\hline $\begin{array}{c}\text { Fang, Holsapple, } \\
\text { 2007, [17] }\end{array}$ & $\begin{array}{l}\text { Hypertext links for } \\
\text { navigation varied in } \\
\text { structure: subject } \\
\text { oriented, usage } \\
\text { oriented and } \\
\text { combination of } \\
\text { above two. }\end{array}$ & $\begin{array}{l}\text { Navigation time, } \\
\text { Correct answers to } \\
\text { a test, Subjective } \\
\text { opinions. }\end{array}$ & $\begin{array}{l}\text { Information web } \\
\text { site. }\end{array}$ & $\begin{array}{l}\text { Experime } \\
\text { ntal }\end{array}$ & Statistical & $\begin{array}{l}\text { Usage oriented structure or combined structure } \\
\text { more useable for simple and complex tasks. }\end{array}$ \\
\hline $\begin{array}{l}\text { McCarthy, Sasse, } \\
\text { Riegelsberger, } \\
\text { 2003, [16] }\end{array}$ & Left, Top, Right. & $\begin{array}{l}\text { Eye movements, } \\
\text { Finding the target } \\
\text { on navigation } \\
\text { menu, Site } \\
\text { complexity, Time. }\end{array}$ & $\begin{array}{l}\text { Internet service } \\
\text { provider web } \\
\text { site. }\end{array}$ & $\begin{array}{l}\text { Experime } \\
\text { ntal }\end{array}$ & Statistical & $\begin{array}{l}\text { Complex site took longer for searching. Left } \\
\text { menu significantly performed better for first } \\
\text { page visit. User glances were mostly towards the } \\
\text { central part of the screen. Menu position not } \\
\text { significant. }\end{array}$ \\
\hline $\begin{array}{l}\text { Burrell, Sodan, } \\
2006,[15]\end{array}$ & $\begin{array}{l}\text { Top tabbed, Top, } \\
\text { Left, Top and } \\
\text { bottom, Top and } \\
\text { left, Top and right. }\end{array}$ & $\begin{array}{l}\text { Subjective } \\
\text { opinions. }\end{array}$ & $\begin{array}{l}\text { Information web } \\
\text { site. }\end{array}$ & $\begin{array}{c}\text { Experime } \\
\text { ntal }\end{array}$ & Statistical & Tabbed top menu preferred. \\
\hline $\begin{array}{l}\text { Bernard, Hamblin, } \\
\text { Chaparro, 2003, } \\
{[14]}\end{array}$ & $\begin{array}{l}\text { Top, Left, Index } \\
\text { (links in the centre } \\
\text { of page). }\end{array}$ & $\begin{array}{l}\text { Time, Subjective } \\
\text { opinions. }\end{array}$ & $\begin{array}{l}\text { Ecommerce web } \\
\text { site. }\end{array}$ & $\begin{array}{l}\text { Experime } \\
\text { ntal }\end{array}$ & Statistical & $\begin{array}{l}\text { Index faster. Some evidence for index menu } \\
\text { being preferred by users. }\end{array}$ \\
\hline $\begin{array}{c}\text { Murano, Lomas, } \\
\text { 2015, [13] }\end{array}$ & $\begin{array}{l}\text { Top, Left, Right, } \\
\text { Bottom. }\end{array}$ & $\begin{array}{l}\text { Time (task), Errors, } \\
\text { Mouse clicks, } \\
\text { Subjective } \\
\text { opinions. }\end{array}$ & $\begin{array}{l}\text { Ecommerce web } \\
\text { site. }\end{array}$ & $\begin{array}{l}\text { Experime } \\
\text { ntal }\end{array}$ & Statistical & $\begin{array}{l}\text { Least errors - in order: Top, left. No difference } \\
\text { between top and right menus. Least mouse } \\
\text { clicks - in order: Top, left. }\end{array}$ \\
\hline $\begin{array}{c}\text { Murano, Oenga, } \\
\text { 2012, [12] }\end{array}$ & $\begin{array}{l}\text { Left vertical, Top } \\
\text { fisheye, Real } \\
\text { supermarket top } \\
\text { horizontal. }\end{array}$ & $\begin{array}{l}\text { Time, Errors, } \\
\text { Overall success, } \\
\text { Subjective } \\
\text { opinions. }\end{array}$ & $\begin{array}{c}\text { Ecommerce web } \\
\text { site. }\end{array}$ & $\begin{array}{l}\text { Experime } \\
\text { ntal }\end{array}$ & Statistical & $\begin{array}{c}\text { Errors more with left vertical and top fisheye } \\
\text { menu for } 1 \text { task out of } 5 \text {. Some significance to } \\
\text { show real supermarket top horizontal menu was } \\
\text { preferred. }\end{array}$ \\
\hline
\end{tabular}




\begin{tabular}{|c|c|c|c|c|c|c|}
\hline $\begin{array}{c}\text { Leuthold, } \\
\text { Schmutz, Bargas- } \\
\text { Avila, Tuch, } \\
\text { Opwis, 2011, [11] }\end{array}$ & $\begin{array}{l}\text { Left vertical (three } \\
\text { types: Simple menu, } \\
\text { Extended menu, } \\
\text { Dynamic menu). }\end{array}$ & $\begin{array}{l}\text { Number of eye } \\
\text { fixations, Time to } \\
\text { do first click, } \\
\text { Correctness of the } \\
\text { first click, } \\
\text { Navigations } \\
\text { strategy, Subjective } \\
\text { opinions. }\end{array}$ & $\begin{array}{l}\text { Ecommerce web } \\
\text { site. }\end{array}$ & $\begin{array}{l}\text { Experime } \\
\text { ntal }\end{array}$ & Statistical & $\begin{array}{l}\text { First clicks were more successful for complex } \\
\text { and simple tasks with the Extended menu. For } \\
\text { simple tasks participants used fewer eye } \\
\text { fixations with the extended menu. For complex } \\
\text { tasks participants used fewer eye fixations with } \\
\text { the extended menu. For simple tasks } \\
\text { participants were faster with the simple menu. } \\
\text { For complex tasks participants were faster with } \\
\text { the extended menu. The extended menu was } \\
\text { perceived by participants to be easier and more } \\
\text { helpful than the other two menus. }\end{array}$ \\
\hline $\begin{array}{l}\text { Patsula, Detenber, } \\
\text { Theng, 2010, [10] }\end{array}$ & $\begin{array}{c}\text { Study 1: Structured } \\
\text { rule-based, } \\
\text { Structured semantic- } \\
\text { based, Unstructured } \\
\text { mismapped, } \\
\text { Unstructured } \\
\text { random design. } \\
\text { Study 2: Structured, } \\
\text { based on } \\
\text { PhotoImpression 3.0 } \\
\text { and Unstructured, } \\
\text { based on Norton } \\
\text { Anti Virus 4.0. }\end{array}$ & $\begin{array}{l}\text { Study 1: Retention, } \\
\text { time, errors, } \\
\text { Subjective } \\
\text { opinions. } \\
\text { Study 2: Retention, } \\
\text { time, errors, } \\
\text { Subjective } \\
\text { opinions. }\end{array}$ & $\begin{array}{c}\text { Study 1: Web } \\
\text { menus with } \\
\text { abstract content } \\
\text { consisting of } \\
\text { arbitrary words } \\
\text { and characters. } \\
\\
\text { Study 2: Menus } \\
\text { based on } \\
\text { PhotoImpressio } \\
\text { n } 3.0 \text { and } \\
\text { Norton Anti } \\
\text { Virus 4.0. }\end{array}$ & $\begin{array}{l}\text { Experime } \\
\text { ntal }\end{array}$ & $\begin{array}{c}\text { Study 1: } \\
\text { Statistical } \\
\quad, \\
\text { Interview } \\
\text { s. } \\
\text { Study 2: } \\
\text { Statistical } \\
\quad, \\
\text { Question } \\
\text { naire, } \\
\text { Interview } \\
\text { s. }\end{array}$ & $\begin{array}{l}\text { Study 1: Retention, time and errors were better } \\
\text { with the structured menus. Almost half of all } \\
\text { participants felt the unstructured menus needed } \\
\text { more mental effort. } \\
\text { Study 2: Retention, time and errors were better } \\
\text { with the structured menus. Participants seemed } \\
\text { to engage in behaviour involving structure } \\
\text { processing. }\end{array}$ \\
\hline $\begin{array}{c}\text { Melguizo, Vidya, } \\
\text { van Oostendorp, } \\
2012,[9]\end{array}$ & $\begin{array}{c}\text { Left vertical } \\
\text { expandable, Left } \\
\text { vertical sequential. }\end{array}$ & $\begin{array}{c}\text { Task accuracy, } \\
\text { Task response time, } \\
\text { Lostness. }\end{array}$ & $\begin{array}{l}\text { Information web } \\
\text { site. }\end{array}$ & $\begin{array}{l}\text { Experime } \\
\text { ntal }\end{array}$ & Statistical & $\begin{array}{l}\text { No significance for menu type and task } \\
\text { accuracy, task response time and lostness. }\end{array}$ \\
\hline $\begin{array}{l}\text { Pittsley, Memmot, } \\
\text { 2012, [8] }\end{array}$ & $\begin{array}{l}\text { Tabbed horizontal } \\
\text { menu and left } \\
\text { vertical context } \\
\text { menu with a larger } \\
\text { font (both with the } \\
\text { same labels). Larger } \\
\text { tabbed horizontal } \\
\text { menu only. } \\
\text { 'Comparison group' } \\
\text { (not fully described } \\
\text { in the paper). }\end{array}$ & $\begin{array}{l}\text { Monthly usage on } \\
\text { each information } \\
\text { guide, page and } \\
\text { secondary pages. }\end{array}$ & $\begin{array}{l}\text { Information web } \\
\text { site. }\end{array}$ & $\begin{array}{l}\text { Experime } \\
\text { ntal }\end{array}$ & $\begin{array}{l}\text { Statistical } \\
\text {, Usage } \\
\text { data }\end{array}$ & $\begin{array}{l}\text { Both prototype 'menus' showed an increase in } \\
\text { secondary page hits compared to the } \\
\text { 'comparison group'. }\end{array}$ \\
\hline
\end{tabular}




\section{WAYS FORWARD FOR INVESTIGATING MENU DESIGN}

An examination of these studies shows that there is no totally clear picture to suggest which menu type or position on the screen may be optimal in terms of performance, e.g. fewer errors and less clicks etc. There is also no totally clear picture regarding which type of menu or position may be preferred by the majority of users. These statements regarding a totally clear picture are important because designers and developers tend to like to have clear and unambiguous guidelines when developing elements of a user interface.

Some aspects that loosely can be linked across the studies are that the strongest suggestion of better performance comes from menus which are as straightforward as possible and well structured. Also in the study by Murano and Lomas [13] the menu placed at the bottom of the screen horizontally performed worst with users (finding not included in the table above).

In some cases, the evidence suggests a 'leaning' towards a top horizontal menu being the best performer.

Most studies used some sort of web site in their evaluations and most studies used exclusively some type of statistical analysis of the data. A few studies used interviews and other more qualitative methods. Interviews were the most frequently occurring qualitative method used. One study also used usage data in their analysis. Further, most studies investigated some sort of performance in terms of task times and errors and most recorded some kind of subjective opinions.

Therefore it is clear that further studies are needed and the studies presented above document some indications. However in the authors' opinions indications are often arguable.

One reason for this rather unclear picture could be to do with the fact that most users these days have become so used to seeing and interacting with different types of menus and in different positions on the screen, that it reduces significant effects of performance and even preferences. One way to test this statement would be to have complete novices to menus and their screen positioning taking part in extensive evaluations. However in practice obtaining such a sample of users is challenging as these days even children are being exposed to computer technology from birth onwards.

A further observation regarding these studies is that they all applied an 'experimental' type method to data collection. While this is an accepted and very good method and the authors do not seek to criticise it, it is the authors' idea that since the results are quite varied and do not show any overall patterns that could help designers and developers, perhaps some studies using more qualitative techniques could shed further light on the matter. Some possible approaches could be to use more ethnographic, interview or case study approaches.

A further way forward that could be looked at concerning all menu types and their positioning on the screen would be to try and apply more universal design [21] principles. The first aspect we will not dwell on here but needs mentioning is for developers to ensure that their implementation follows appropriate guidelines to help achieve aspects of universal design and accessibility (e.g. WCAG [22] etc.). The second aspect is to meet the challenge of navigation in a way that makes things as easy as possible (e.g. Apple Inc [23] has guidelines for menu design to aid simplicity) for as many users as possible. These first two aspects the authors consider to be works in progress, because many are trying to achieve what we suggest. However, a third aspect to consider in the realm of catering for as many diverse users as possible could be to develop navigation systems (menus and positioning) that allow for more tailoring by the end user. Some examples include: being able to easily enlarge a menu, change the colour and shading of menus to allow for different types of vision and allow users to be able to move a menu to some other part of the screen with the content of the application or web page adjusting itself automatically.

While some of these ideas would require more implementation effort (until more implementation libraries are available), it would nevertheless aid the goal of user interfaces being as universally designed as possible. The authors also suggest that while user-tailoring can be a good thing as suggested above, it can also be implemented in a way that could actually confuse users more. This would require designers and developers to strike a balance between usertailoring and a greater learning curve and/or the need to use a lot more time to tailor options.

\section{CONCLUSIONS}

This review paper has been written with the purpose of bringing together a body of research concerning menus and their positioning on the screen. Another purpose is to allow researchers, designers and developers a quick at a glance view of the most important work done in this field. Furthermore, this paper contributes by suggesting some ways forward for this research area.

Overall, the authors would like to see if there is some clear menu type that is better and preferred by users. However if this does not materialize, the authors feel that some improvements in universal design could go a long way to improve current menus and navigation.

\section{REFERENCES}

[1] Statoil, http://www.statoil.no/no_NO/pg1334082177637/extra.html, 2016, Accessed March 2016.

[2] Oslo and Akershus University College of Applied Sciences, http://www.hioa.no, 2016, Accessed March 2016.

[3] Luleå University of Technology, http://www.ltu.se/?l=en, 2016, Accessed March 2016.

[4] J. M. Rubio and P. Janecek, "Floating pie menus: enhancing the functionality of contextual tools", UIST '02 - Adjunct Proceedings of the 15th annual ACM Symposium on User Interface Software and Technology, 2002.

[5] K. Samp and S. Decker, "Supporting menu design with radial layouts", Proceedings of the International Conference on Advanced Visual Interfaces, ACM, 2010.

[6] G. Bailly, E. Lecolinet and L. Nigay, "Flower menus: a new type of marking menu with large menu breadth, within groups and efficient expert mode memorization", Proceedings of the working conference on Advanced Visual Interfaces, AVI 2008, Napoli, Italy, May 28-30, 2008.

[7] P. Murano and I. N. Khan, "Pie menus or linear menus, which is better?", Journal of Emerging Trends in Computing and Information Sciences, Vol. 6, Issue 9, September 2015.

[8] K.A. Pittsley and S. Memmott, "Improving independent student navigation of complex educational web sites: an analysis of two 
navigation design changes in LibGuides", Information technology and libraries, 31(3), pp. 52-64, 2012.

[9] M.C.P. Melguizo, U. Vidya and H. van Oostendorp, "Seeking information online: the influence of menu type, navigation path complexity and spatial ability on information gathering tasks", Behaviour \& Information Technology, 31(1), pp. 59 - 70, 2012.

[10] P.J. Patsula, B.H. Detenber and Y.L. Theng, "Structure processing of web-based menus", International Journal of human- computer interaction, 26(7), pp. 675 - 702, 2010.

[11] S. Leuthold, P. Schmutz, J.A. Bargas-Avila, A.N. Tuch and K. Opwis, "Vertical versus dynamic menus on the world wide web: eye tracking study measuring the influence of menu design and task complexity on user performance and subjective preference", Computers in Human Behavior, 27, pp. 459 - 472, 2011.

[12] P. Murano and K.K. Oenga, "The impact on effectiveness and user satisfaction of menu positioning on web pages", International Journal of Advanced Computer Science and Applications, 3: 9, 2012.

[13] P. Murano and T.J. Lomas, "Menu positioning on web pages. does it matter?", International Journal of Advanced Computer Science and Applications, Vol. 6, Issue 4, April 2015.

[14] M. L. Bernard, C.J. Hamblin and B.S. Chaparro, "Comparing cascading and indexed menu designs for differences in performance and preference", Proceedings of the Human Factors and Ergonomics Society 47th Annual Meeting - 2003.

[15] A. Burrell and A.C. Sodan, "Web interface navigation design: which style of navigation-link menus do users prefer?", Proceedings of the 22nd International Conference on Data Engineering Workshops,
ICDEW 2006, 3-7 April 2006, Atlanta, GA, USA, IEEE Computer Society, 2006.

[16] J.D. McCarthy, M. A. Sasse, and J. Riegelsberger, "Could i have the menu please? An eye tracking study of design conventions", people and Computers XVII - Designing for Society, pp 401-414, 2004.

[17] X. Fang and C.W. Holsapple, "An empirical study of web site navigation structures' impacts on web site usability", Decision Support Systems, 43: 2, P.476-491, 2007.

[18] B. Yu and S. Roh, "The effects of menu design on information-seeking performance and user's attitude on the world wide web", Journal of the American Society for Information Science and Technology, 53: 11, P.923-933, 2002.

[19] J. Kalbach and T. Bosenick, "Web page layout: a comparison between left and right justified site navigation menus", Journal of Digital Information, Vol 4, No 1, 2003.

[20] [20] X. Faulkner and C. Hayton, "When left might not be right", Journal of Usability Studies, Vol 6, Issue 4, P. 245-256, 2011.

[21] [21] M.F. Story, "Maximizing usability: the principles of universal design", Assistive Technology: The Official Journal of RESNA, 10:1, 412, 1998.

[22] [22] WCAG (2016) https://www.w3.org/WAI/intro/wcag, Accessed March 2016.

[23] [23] Apple Inc. (2016) OS X Human Interface Guidelines, https://developer.apple.com/library/mac/documentation/UserExperience/ Conceptual/OSXHIGuidelines/MenuAppearanceBehavior.html\#//apple_ ref/doc/uid/20000957-CH23-SW1, Accessed March 2016. 